\title{
SUCCESS FACTORS ON THE IMPLEMENTATION OF CERTIFICATION FOR GREEN PROJECT MANAGER (GPM) IN MALAYSIA
}

\author{
Nur Halimah Mohd Saiful Rahim*, Zulhabri Ismail, Rumaizah Mohd Nordin \\ ${ }^{1}$ Faculty of Architecture, Planning and Surveying, Universiti Teknologi MARA (UiTM) \\ Shah Alam, Selangor, Malaysia
}

E-mail: * halimahsaifulrahim@gmail.com,drzulhabri.edu@gmail.com, rumaizah.mnordin@gmail.com

\begin{abstract}
The paper aims to establish the success factors in promoting certified Green Project Managers (GPM) in Malaysia's construction projects. A set of self-administered questionnaires through snowball sampling method was used to retrieve information among 30 respondents within various backgrounds which include project directors, general managers and project managers. Based on the analysis using Statistical Package for the Social Sciences (SPSS), this research has discovered that the main reason GPMs are highly needed in Malaysia's construction industry is to ensure a successful delivery of green development goals. Nevertheless, this research found a number of challenges in promoting certified GPM, which include limited training for project managers that incorporates sustainability elements. This research found that training is significant to equip them with the necessary skills and knowledge towards becoming certified GPM to date, a private sector organization known as Bridget is the sole provider of specific training for GPM in Malaysia. The respondents of this study are limited among project directors, general managers and project managers in the Klang Valley who are currently involved in green building projects. This paper fulfils the recognized need to study the success factors on the implementation of certification for Green Project Managers (GPM) in Malaysia.
\end{abstract}

Keywords: Green Project Manager, Green Management, Green Building, Sustainability

\section{INTRODUCTION}

Beginning in the 19th century, the sustainability concept has caught the attention and recognition of many construction industry players which in turn has triggered plenty of discussions regarding the fundamentals in achieving sustainability to reduce environmental stress (Braganca, Mateus and Koukkari, 2010; Neyestani,2017; Moradi, Hosseini and Yazdani 2018). Moving along the increasing demand for sustainability in the construction industry, Malaysia has introduced the Construction Industry Transformation Plan (CITP) as part of its international agenda to be a model country to the emerging world by having an environmentally sustainable construction industry by the year of 2020. This effort is well aligned with the Eleventh Malaysia Plan that has emphasized, on the many, the aspect of sustainability in Malaysia's development.

Sadaba, Jaen, and Ezcurdia, (2015) claimed that sustainability is frequently encountered with the aspects related to management such as strategies, communications, aims, integration and teamwork. It is well documented in the academic literature by Okland (2015) that it is significant to consider the aspect of sustainability in attaining green project management (Robichaud and Anantatmula, 2011; Aghili, Mohammed, and Ting, 2016). In addition, the concept of sustainability has also been linked to project management as projects are "instruments of change" within organizations, which play an important role in the realization of sustainable business processes and practices (Silvius and Schipper, 2014). 
Project management has traditionally been defined as the application of proper methodology, knowledge, and processes in ensuring the delivery of products or services are on time and within stipulated budget accompanied by an optimal use of resources in meeting, better yet, exceeding customers' needs (Chin, 2016). Moving forward, Green Project Management (GPM) enhances the implementation of project management by incorporating green thinking in decision making throughout a project to minimize the impact on the environment (Maltzman \& Shirley, 2010). A building, for example, is considered a green building whenever the structure and the implementation of processes are eco-friendly and resource-efficient throughout the building's life cycle (Khodadadzadeh, 2016).

While being heavily discussed by the construction industry players, however, the aspect of sustainability, particularly the implementation of green project management, is still inadequate and not specifically or systematically assimilated in most major project management frameworks including, but not limited to, Project Management Body of Knowledge (PMBoK), ICB, ISO 21500:2012 and Project in Control Environment (Prince2). It was revealed in a number of researches that green buildings have not been performing up to the predicted standard due to refusal of a large number project managers and their teams to switch to sustainable project management practices (Lokman \& Abdullah, 2017). In order to achieve a sustainable construction, project managers need to be more proactive in tackling issues concerning sustainability in the first place. Hence, Malaysia has launched its first National Green Project Managers (GPM) Awards in 2015. Nevertheless, despite having been launched for five years, the promotion of certification of GPM is still lacking.

\section{LITERATURE REVIEW}

Previous studies have shown that consideration towards sustainability issues plays a significant role in achieving green project management (Aghili, Mohammed,and Ting, 2016; Okland, 2015; Robichaud \& Anantatmula, 2011; Sadaba, Jaen, \&Ezcurdia, 2015; Tabassi and Argyropoulou, 2016). Nonetheless, in the context of a developing country like Malaysia, the strength and emphasis on sustainability in construction and development has yet to reach an adequate level as many of its challenges have not been properly dealt with (Hwang \& Ng, 2013). Hwang and Ng (2013) and Lokman and Abdullah (2017) have argued that project managers are the key "change agents" in organizations as they are known to have a powerful influence on the efforts towards a sustainable construction to diminish the negative impacts towards the environment. Furthermore, there have been positive correlations between project managers' competencies and successful projects deliveries as proven by many researches over the past couple of decades (Geoghegan \& Dulewicz, 2008; Kissi \&Dainty, 2013;Mir \& Pinnington, 2014; Muller \& Turner, 2010; Nauman \& Khan, 2010; Walker, 2011; Yang \& Wu, 2011).

As previously mentioned, the reorganization of certification of GPM in Malaysia is still deficient despite the National Green Project Managers (GPM) Awards being in placed for five years. Therefore, this research paper aims to explore the limitations towards implementing green project management practices in Malaysia through the participation in green building development. Based on Table 1, it was recorded that the total number of construction projects for the year of 2013, 2014, and 2015 were 5987, 7939 and 6885 respectively. However, the number of construction projects registered with Green Building Index (GBI) were relatively small compared to the overall construction projects being executed in Malaysia for the years mentioned.

Table 1: Comparison analysis of total construction projects

\begin{tabular}{clll}
\hline Year & $\begin{array}{l}\text { Total } \\
\text { projects }\end{array}$ & Construction & $\begin{array}{l}\text { Total } \\
\text { projects }\end{array}$ \\
\hline 2013 & 5985 & 476 \\
2014 & 7939 & 595 \\
2015 & 6885 & 664 \\
\hline \multicolumn{2}{l}{ Source: CIDB (2012) and Green Building Index (2016). }
\end{tabular}

The tiny percentage of GBI-registered construction projects in Malaysia for the said years had stunted GBI's target of achieving a minimum of 200M sq. ft. of green building in Malaysia by the end of 2016. To make things worse, the 2016 target were not even met by the end of 2017 where there were only 195,777,797 sq. ft. of certified green buildings which was $4.2 \mathrm{M}$ sq. $\mathrm{ft}$. short from the original target (Mir \& Pinnington, 2014). This alarming statistics clearly indicates that the GPM need to intervene and play a bigger role to help achieving the GBI's target. 


\subsection{The needs of GPM in Malaysia}

Wang, Yao, and $\mathrm{Wu}(2015)$ claimed that objectives of effective project management include saving time and cost, improving quality and functionality, and maximizing stakeholders' satisfaction. However, most project managers have been undermining the sustainability aspect of construction projects as an integral part of effective project management by ignoring the long-term environmental impacts (Mishra \& Dangayach, 2011). This issue is defined as "conflict" by Shi, Yan, and Zuo (2016), and it is a challenge to Green Project Managers (GPM) as individuals who carry huge responsibilities in developing sustainable solutions to integrate sustainability features as part of their projects' components. This shows that GPM's involvement is crucial in addressing sustainability-related issues in construction.

\subsection{GPM is responsible to avoid cost constraint in management of green buildings}

Although green buildings help a broad range of benefits for the society and environment, green project management is difficult to be implemented due to the fact, as argued by Hwang and $\mathrm{Ng}$, 2013, that green projects are more costly distinguished to conventional projects due to uncertainty and high cost of green equipment and materials. In addition, the high complexity in delivering green projects with overall characteristics that meet environmental requirement of green buildings has also added to the rising cost ( $\mathrm{Li} \& \mathrm{Chew}, 2011)$. This situation is unfavorable to the GPM as they are expected to manage and deliver projects within allocated budgets (Hwang \& Ng, 2013). The expected idea of responsibilities of PM in managing and tight budgets with small profit margins on green project is one of the heightened perceptions of risks associated with going green (Robichaud \& Anantatmula, 2011).Hence, GPM's involvement is vital in improving project performance by means of optimizing projects' cost which will have impacts on green building projects ( $\mathrm{Li}, \mathrm{Chen}, \& \mathrm{Chew}, 2011)$. Furthermore, a research done 30 years back has found that a continuous success of construction projects relies on cost effectiveness which create a competitive advantage for organizations over their competitors (Ashley, 1987).

Therefore, appointing competent GPMs to manage green and sustainable building constructions is one of the remedies needed in achieving maximum cost efficiency while delivering projects within stipulated timeframe in accordance with project planning, scheduling, and controlling (Lokman \& Abdullah, 2017).

\subsection{GPM is responsible to successfully deliver green developments}

Despite cost and profit existence as the main elements defining the success of a project, some research conducted has proven that there is a well-known gap of green development as there are many PMs who reluctant to accept the changing direction towards going green (Lokman \& Abdullah, 2017). In Malaysia, a succesful implementation of green building constructions relies heavily on the effectiveness of the PMs and project teams (Lokman \& Abdullah, 2017). According to Robichaud \& Anantatmula (2011), a succesful green building project needs to be kicked off by nominating an experienced green building consultant and project manager during the project's feasibility study stage.

\subsection{PM reacts as a catalyst "agent" to achieve green goals}

Sustainability in construction is mainly achieved through the implementation of green building construction practice. According to Vyas (2017), environmental, social, and economic are the three pillars of sustainability that need to be focused on with regards to construction and operation of buildings in pursuing a sustainable development. As PM's involvement directly contributes to $34 \%-47 \%$ of a project's success, it is evident that a competent PM should be appointed by an organization to maximize the benefits deployed from the construction of a green building which include, but not limited to, reduction in carbon dioxide emissions (Lokman \& Abdullah, 2017). As the global construction industry is actively evolving towards becoming more sustainable, there is a critical need to refashion the role of PMs to include portfolio specifically addressing the issue of climate change and environmental protection (Hwang \& Ng, 2013). Moreover, there have been an improvement in stakeholders' recognition towards green building technologies as they are more aware of the benefits which include energy conservation and consequently, utility bills reduction (Brotman, 2016). Hence, it is important for PMs to focus on effective coordination between the design consultants and construction teams in incorporating various technological innovations to enhance the success possibility of green building projects (Shi, Yna, \&Zuo, 2016). 
Table 2: Summary of need of certifying GPM

\begin{tabular}{|c|c|c|c|c|c|c|c|c|c|}
\hline & $\begin{array}{l}\text { Need of certifying Green } \\
\text { Project Manager (GPM) in } \\
\text { Malaysia construction } \\
\text { project }\end{array}$ & $\begin{array}{l}\text { (Hwang } \\
\& \quad \mathrm{Ng} \\
2013)\end{array}$ & $\begin{array}{l}\text { (Li, } \\
\text { Chen, \& } \\
\text { Chew, } \\
\text { 2011) }\end{array}$ & $\begin{array}{l}\text { (Robicha } \\
\text { ud\&Ana } \\
\text { ntatmula, } \\
\text { 2011) }\end{array}$ & $\begin{array}{l}\text { (Sadaba, } \\
\text { Jaen, } \\
\text { \&Ezcurdi } \\
\text { a, 2015) }\end{array}$ & $\begin{array}{l}\text { (Lokman } \\
\& \\
\text { Abdullah } \\
\text {, 2017) }\end{array}$ & $\begin{array}{l}\text { (Marte } \\
\text { ns \& } \\
\text { Carval } \\
\text { ho, } \\
2016)\end{array}$ & $\begin{array}{l}\text { (Wang, } \\
\text { Yao, \& } \\
\text { Wu, } \\
2015 \text { ) }\end{array}$ & Ranking \\
\hline i. & $\begin{array}{l}\text { Project manager is } \\
\text { responsible to avoid cost } \\
\text { constraint in management } \\
\text { green building. }\end{array}$ & $\sqrt{ }$ & $\sqrt{ }$ & $\sqrt{ }$ & $X$ & $\sqrt{ }$ & $X$ & $X$ & $4 / 7$ \\
\hline ii. & $\begin{array}{l}\text { Project Manager is of great } \\
\text { importance to successfully } \\
\text { deliver green development }\end{array}$ & $X$ & $\sqrt{ }$ & $\sqrt{ }$ & $X$ & $\sqrt{ }$ & X & $\mathrm{X}$ & $3 / 7$ \\
\hline iii. & $\begin{array}{l}\text { Project manager acts as a } \\
\text { catalyst "agent" to achieve } \\
\text { goals of green to minimize } \\
\text { impact of environment. }\end{array}$ & $\sqrt{ }$ & $X$ & $X$ & $X$ & $\sqrt{ }$ & $X$ & $X$ & $2 / 7$ \\
\hline
\end{tabular}

\subsection{Challenges in GPM implementation}

According to Herazo (2012), a successful project management is closely linked to effectiveness in incorporating the aspect of sustainability in client's overall strategic management for a specific project. Nevertheless, the involvement of PMs who are well trained in the sustainability area is insufficient in dealing with client's sustainability demands in conjunction with product design, project processes, and organization commitment (Aarseth \& Ahola, 2017). Due to this, the implementation of GPMs in the construction industry is definitely not a simple task to be accomplished.

\subsection{Financial barriers}

Generally, sustainable practices require higher upfront capital which contributes to the escalation of project cost (Abidin, 2009). Saleh (2015) claimed that cost analysis studies conducted on sustainable construction practices have shown an increase of cost ranging from $0-18 \%$, the additional cost; known as "green premium" that is considerably higher. This causes a perception of rising in unsubstantiated cost among professionals in construction industry Robichaud and Anantatmula (2011) as one of the challenges in promoting GPMs who are responsible for getting projects completed within established timeframe and cost. However, Sadaba, Jaen and Ezcurdia (2015) provided one of the solutions through Corporate Social Responsibility (CSR) that demonstrates integrity, credibility and reputation embedded through leadership as one of factors in going green and sustainable in project management including through effective communication. Wang, Yao, and $\mathrm{Wu},(2015)$ claimed that effective communication can avoid unnecessary cost in every stages of a project effectively.

Despite the unsubstantiated cost, the initial extra cost also is a big concern in implementing sustainable construction (Lokman\& Abdullah, 2017). This can create a fear of higher investment costs, long Pay-back period, low client's profitability, ignorance of life cycle cost, and lack of financial resources as primary barriers to the implementation of sustainable construction (Ametepey, 2015).

\subsection{Market demand}

Market demand towards sustainable construction has pushed many clients and stakeholders to invest in it by engaging PMs who are well trained in the sustainability area to ensure successful projects deliveries despite the fact that the construction industry is categorized as extremely competitive, high risk, and usually produce a low profit margin in comparison with other industries (Mokhtariani, 2017).In addition, due to the environmental benefits, green building is capable of becoming a symbolic opportunity for growth in construction management, product development, and information exchange as well as being considered as an industry with highest potential growth in the next 5 to 10 years while being a market driven to environmental protection (Robichaud\&Anantatmula ,2011 ; Wang, Yao, \& Wu, 2015; Lokman\& Abdullah,2017).

Besides that, increasing demand among end users (home buyers and tenants) is also significant (Hakkinen 
\& Belloni, 2011). If professional clients recognize the increasing or existing end users' demand for sustainable buildings, they definitely will decide to response to this demand. However, it is noted that promoting certified GPMs would not be a success if there is insufficiency in sustainable green building's demand.

\subsection{Limited training for project manager that is considered as sustainability element}

PMs who are well trained in sustainability is a driving factor in attaining sustainability (Sadaba, Jaen, and Ezcurdia, 2015). Therefore, it is essential that PMs undergo proper trainings in order for them to better manage green construction projects as well as to increase their likelihood of delivering a successful green construction project in the future (Lokman and Abdullah, 2017). However, as previously stated, Bridg it has been and is still the only provider for GPM's specific training in Malaysia. This clearly shows that the green project implementation in Malaysia is stunted by, of many reasons, limited training.

\section{9 "Going Green" is something new to the participants in the construction industry.}

According to Aarseth and Ahola (2017), identifying suitable strategies to implement sustainability is a starting point for a development of a more holistic and thorough approach by scholars, project management associations, and practitioners in understanding the sustainability skills and competencies needed by PMs. Sourani (2011) claimed that low level of awareness and understanding on the concept of sustainability not only exists among people working in public client organizations (including senior procurement decision-makers) but also among other stakeholders' organizations and groups (such as contractors, funding organizations and users). Ametepey (2015) later added that it is quite common for many industry players to have misunderstandings on the concept of sustainability and this has caused a major difficulty in the implementation of sustainable construction. Not helping the situation, the sustainability area has not been given enough coverage and emphasis in today's project management guidelines, standards, and competence requirements (Eskerod \& Huemann, 2013). Consequently, this has caused many participants in the construction industry to not have clear ideas to effectively and efficiently manage GB projects, with the perspective of GB is new while involving many complex processes Lokman and Abdullah (2017).

\subsection{Project managers refuse to accept the change to sustainable/ green project management}

Many PMs and project teams prefer to implement conventional methods in their projects as opposed to the new, greener practices as they are having difficulties in adapting to the new, sustainable construction (Lokman\& Abdullah, 2017). As a result, clients' demand towards the implementation of sustainable construction practices will stay minimal according to Khalfan, Noor, \& Maqsood (2015) as supported by Davies (2017) who has found that the greater percentage of clients are more interested in the upfront cost rather than the long term benefits of sustainable construction.

Table 3: Summary of the Challenges of Promoting Certified GPM in Malaysia Construction Industry

\begin{tabular}{|c|c|c|c|c|c|c|c|c|c|}
\hline & $\begin{array}{l}\text { The Challenges of } \\
\text { Promoting Certified Green } \\
\text { Project Manager(GPM) in } \\
\text { Malaysia Construction } \\
\text { Industry }\end{array}$ & $\begin{array}{l}\text { (Hwang } \\
\& \mathrm{Ng} \\
2013 \text { ) }\end{array}$ & $\begin{array}{l}\text { (Li, } \\
\text { Chen, } \\
\& \\
\text { Chew, } \\
\text { 2011) }\end{array}$ & $\begin{array}{l}\text { (Robich } \\
\text { aud\&A } \\
\text { nantatm } \\
\text { ula, } \\
\text { 2011) }\end{array}$ & $\begin{array}{l}\text { (Sadaba } \\
\text {, Jaen, } \\
\text { \&Ezcur } \\
\text { dia, } \\
\text { 2015) }\end{array}$ & $\begin{array}{c}\text { (Lokma } \\
\mathrm{n} \\
\& \\
\text { Abdulla } \\
\text { h, 2017) }\end{array}$ & $\begin{array}{l}\text { (Marte } \\
\text { ns } \\
\text { \&Carva } \\
\text { lho, } \\
\text { 2016) }\end{array}$ & $\begin{array}{l}\text { (Wang, } \\
\text { Yao, \& } \\
\text { Wu, } \\
2015 \text { ) }\end{array}$ & Ranking \\
\hline i. & Financial barriers. & & & & & & & & \\
\hline & & $\sqrt{ }$ & $\mathrm{X}$ & $\sqrt{ }$ & $\sqrt{ }$ & $\sqrt{ }$ & $\sqrt{ }$ & $\sqrt{ }$ & $6 / 7$ \\
\hline 11. & $1 \mathrm{Va}$ & $X$ & X & $\sqrt{ }$ & $\sqrt{ }$ & $\sqrt{ }$ & $\sqrt{ }$ & $X$ & $4 / 7$ \\
\hline iii & Limited training for & & & & & & & & \\
\hline . & $\begin{array}{l}\text { Project Manager that } \\
\text { consider sustainability } \\
\text { Elements. }\end{array}$ & X & X & $\mathrm{X}$ & $\sqrt{ }$ & $\sqrt{ }$ & $\sqrt{ }$ & $\mathrm{X}$ & $3 / 7$ \\
\hline iv & $\begin{array}{l}\text { "Going green" is } \\
\text { something new towards } \\
\text { participants in the } \\
\text { Construction industry. }\end{array}$ & $\mathrm{X}$ & $\sqrt{ }$ & $\mathrm{X}$ & $\mathrm{X}$ & $\sqrt{ }$ & $\mathrm{X}$ & $\mathrm{X}$ & $2 / 7$ \\
\hline
\end{tabular}




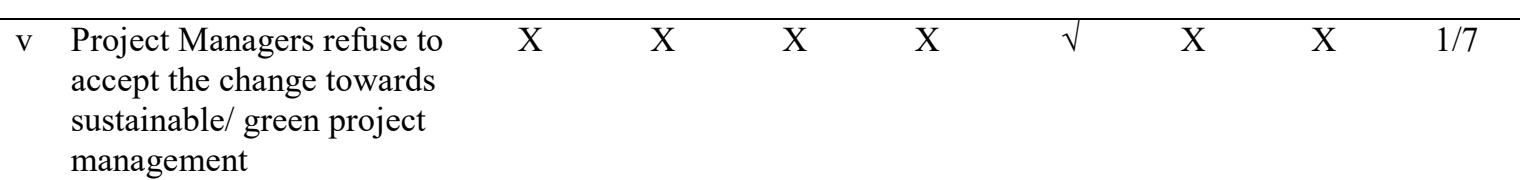

\subsection{Success factor in GPM implementation}

In Malaysia, the demand for green buildings are, as reported, expected to grow as many organizations are moving towards improving their corporate social responsibility as well as emphasizing on environmental awareness. Many evidences have demonstrated that it is financially possible to implement green buildings technology (Aliagha \& Hashim, 2013) and hence, it is crucial to determine the success factor in GPM implementation to intensify the growth of green environment.

\subsection{Project managers require skills and knowledge in order to manage green projects professionally and successfully}

Studies have shown that success of projects heavily rely upon the competency level of project managers (Avots, 1969; Belassi\&Tukel, 1996; Liikamaa, 2015; Lokman\& Abdullah, 2017). Project management competency is attained by combination of knowledge acquired during training, skills developed through experience, and application of the acquired knowledge. Hwang and $\mathrm{Ng}$ (2013) argued that it is highly important for project managers to fully equip themselves with technical skills and knowledge in green technology in order to successfully and professionally manage green projects. Hence, it is proven that a project manager needs to master all the required skills and knowledge in green technology to be considered as competent.

\subsection{Training module is important in producing a successful green construction project.}

To date, a large percentage of studies conducted on project management has been revolving around the importance of trainings. As a matter of fact, famous institutions such as PMI and IPMA even have specified modules for project management training. According to Martens and Carvalho (2016), main focus in the process of promoting environmental sustainability is to educate and train project managers regarding green initiatives. Furthermore, it is mandatory for on-site construction personnel to complete a green building training session (Robichaud\&Anantatmula, 2011) in addition to the PMs having the capabilities of creating possibility of green innovations to be incorporated in their projects (Maltzman and Shirley, 2010). Therefore, Lokman and Abdullah (2017) suggested that a training module to be established in an effort to increase green projects' management skills among project managers who already have ethical nature leaning towards sustainability (Sadaba, Jaen, \&Ezcurdia, 2015).

\subsection{L ack of Ethical aspect among project managers (Leadership among PMs have value towards the success of projects)}

According to Silvius and Schipper (2014), "Code of Ethics and Professional Conduct" as described in Project Management Institute (PMI) explained that PMs need to have "decisive or influencing role" to help them decide based on the best interest of society, public safety, and the environment. In addition, Sadaba, Jaen, and Ezcurdia (2015) also claimed that being ethical is fundamental in project administrator training and accreditation towards achieving sustainability. This is due to ethics approach that is capable of increasing satisfaction and customer loyalty as well as creating harmony, brotherhood, trust, value and morality among the team members Mishra and Dangayach (2011 citated in Wang, Yao, \&2015). Additionally, Martens and Carvalho (2016) claimed that over 50\% of PMs in a survey group do take into account ethical aspects when making decision regarding projects. Hence, this shows that ethical competency is just as important as professional and political competency for project managers. (Jałocha, Krane, \&Ekambaram, 2014).

\subsection{PMs Lack competencies to consider the sustainability aspect in their project}

Lokman and Abdullah (2017) claimed that role of PMsis to use their competency in incorporating in their projects sustainability's aspects, which have been underemphasized in the construction industry. Nevertheless, Silvius and Schipper (2014) claimed that there is a discrepancy in standard between a normal project management competency and a green project management competency in which the green project management competency emphasizes sustainability by requiring future PMs to develop consulting skills to better prepare themselves to work 
out a complex project in conjunction with sustainability. The implementation of sustainable development will be stunted if PMs are not competent enough to integrate the aspect of sustainability in their projects. Therefore, the existing gap between normal project management competencies and green project management competencies need to be addressed accordingly to better implement sustainability in development and construction (Silvius \& Schipper, 2014).

Table 4: Summary of the Success Factor of GPM Implementation in Construction Industry

\begin{tabular}{|c|c|c|c|c|c|c|c|c|c|}
\hline & $\begin{array}{l}\text { The Success Factor of } \\
\text { GPM Implementation i } \\
\text { Construction Industry. }\end{array}$ & $\begin{array}{l}\text { (Hwang } \\
\& \mathrm{Ng} \text {, } \\
\text { 2013) }\end{array}$ & $\begin{array}{l}(\mathrm{Li}, \\
\text { Chen, \& } \\
\text { Chew, } \\
\text { 2011) }\end{array}$ & $\begin{array}{l}\text { (Robich } \\
\text { aud\&A } \\
\text { nantatm } \\
\text { ula, } \\
\text { 2011) } \\
\end{array}$ & $\begin{array}{l}\text { (Sadaba, } \\
\text { Jaen, } \\
\text { \&Ezcurd } \\
\text { ia, 2015) }\end{array}$ & $\begin{array}{c}\text { (Lokma } \\
\text { n } \\
\& \\
\text { Abdulla } \\
\text { h, 2017) } \\
\end{array}$ & $\begin{array}{l}\text { (Marten } \\
\text { s } \\
\text { \&Carval } \\
\text { ho, } \\
\text { 2016) }\end{array}$ & $\begin{array}{l}\text { (Wang, } \\
\text { Yao, \& } \\
\text { Wu, } \\
2015)\end{array}$ & Ranking \\
\hline i. & $\begin{array}{l}\text { Project Managers } \\
\text { require } \\
\text { skills and knowledge in } \\
\text { order to manage green } \\
\text { project professionally } \\
\text { and } \\
\text { successfully }\end{array}$ & $\sqrt{ }$ & $\sqrt{ }$ & $\sqrt{ }$ & $X$ & $\sqrt{ }$ & X & $\sqrt{ }$ & $5 / 7$ \\
\hline ii. & $\begin{array}{l}\text { Training module is } \\
\text { important in producing } \\
\text { a }\end{array}$ & X & X & $\sqrt{ }$ & $\sqrt{ }$ & $\sqrt{ }$ & $\sqrt{ }$ & $X$ & $4 / 7$ \\
\hline & $\begin{array}{l}\text { successful green } \\
\text { construction project }\end{array}$ & & & & & & & & \\
\hline iii & $\begin{array}{l}\text { Lack of ethical aspect } \\
\text { among project } \\
\text { manager }\end{array}$ & X & $\mathrm{X}$ & X & $\sqrt{ }$ & $X$ & $\sqrt{ }$ & $\sqrt{ }$ & $3 / 7$ \\
\hline & $\begin{array}{l}\text { (Leadership among } \\
\text { project } \\
\text { managers have value } \\
\text { for } \\
\text { success of project) }\end{array}$ & & & & & & & & \\
\hline iv & $\begin{array}{l}\text { Project Manager's lack } \\
\text { of } \\
\text { competencies to } \\
\text { consider } \\
\text { sustainability aspect in } \\
\text { their project }\end{array}$ & $\mathrm{X}$ & $\mathrm{X}$ & $\mathrm{X}$ & $\mathrm{X}$ & $\sqrt{ }$ & $\mathrm{X}$ & $\mathrm{X}$ & $1 / 7$ \\
\hline
\end{tabular}

\section{RESEARCH METHODOLOGY}

The aim of the research is to establish the success factors in the certification of GPM. Therefore, a thorough literature review was completed and a quantitative approach for data collection was adopted. In this case, the data was collected through self-administered questionnaires were 5-point Likert scale ( $1=$ strongly disagree; $5=$ strongly agree) were used to extend which of the affected the respondents.

Snowball sampling was adopted where the potential respondents project manager(s) involved in green building) were hard to find and the sample cannot be calculated. In addition, Biernacki and Waldorf (1981) claimed that this sampling allows for studies to take place where otherwise are impossible to be conducted due to lack of participants. According to Johnson (2014), snowball sampling is where research respondents recruit other respondents who share the same characteristic of the research purpose. This method works best when the focus of the study is on issue that concerning a relatively private matter and directly requires the knowledge of specific respondents for study. Thirty (30) respondents from various backgrounds that relates to PMs who involved in green building project were identified either through face to face or telephone interviews return through this sampling techniques (Marshall \& Cardon, 2013). This is a sufficient number to analyze the data as study proof that $30-50$ people is sufficient for any type of random sampling (Omair, 2014). Snowball sampling also able to verify the respondents' accounts, when 
possible, through third parties where data sources were triangulated (Denzin, 1970; Webb, Campbell, \& Schwartz, 1966). In many cases, third-party verification was accomplished through a person (known as a locator) by contacting respondents personally known by him or her to fit the research criteria. This is the person who literally would start a snowball (Biernacki\&Waldorf, 1981).

Table 5: Research Methodology

\begin{tabular}{clcc}
\hline OBJECTIVES & RESEARCH & RESEARCH & SAMPLE \\
& QUESTIONS & TECHNIQUES & \\
\hline
\end{tabular}

To explore the need of certified Green Project Manager (GPM) in Malaysia construction project.

To identify the limitations of promoting certified Green Project Manager (GPM) in Malaysia construction project

To determine the critical success factor of the implementation of certified Green Project Manager (GPM) professional in Malaysia construction project.
RQ1: What are the roles of
certified Green Project
Manager (GPM) in
Malaysia construction industry?

RQ2: What are the limitations of certified Green Project Manager (GM) in Malaysia construction project?

$\begin{array}{ll}\text { Self-administered } & \text { Project } \\ \text { questionnaires (face to } & \text { Manager(s) who } \\ \text { face / telephone } & \text { are involved in } \\ \text { interviews) through } & \text { green projects }\end{array}$
snowball sampling
RQ3: What are the success factors of certified Green Project Manager (GM) in Malaysia construction industry

\section{RESULTS AND DISCUSSION}

This section, descriptive analysis had been used using SPSS statistics throughout the data analysis. There are four (4) sections as such; each section would address the respective research intentions as tabulated in Table VI. Then, the results were summarized as shown in Table VII that is categorized into their mean score and ranks across the data.

Table 6: Details / Area of Research

\begin{tabular}{clc}
\hline Section & \multicolumn{1}{c}{ Details/ Area of research } & Objective \\
\hline A & Respondent's Demographic Background & General information \\
B & The need of certified Green Project Manager (GPM) & 1 \\
C & Limitations of promoting certified Green Project Manager (GPM) & 2 \\
D & Success factors of promoting certified Green Project Manager & 3 \\
& $(\mathrm{GPM})$ & \\
\hline
\end{tabular}

\subsection{Respondent's demographic background}

The purpose of this section is to determine the sustainability of the respondents and to confirm the reliability of the primary data in the light of this research study. It is vital to provide respondents' details in order to get a glimpse of their backgrounds which improve the reliability and consistency of the response throughout the research.

In summary, the distribution of the respondents' years of experience was found to be as follows: less than 5 years $(26.7 \%), 5-10$ years $(26.7 \%), 10-15$ years $(20 \%)$, and above 15 years $(26.7 \%)$. It is presented that the 
respondents' years of experience is equally distributed between the different groups of years.

Overall, $90 \%$ of the respondents who participate in this survey are those who directly involved in managing projects from top management and had comprehensive experiences in the construction field. However, there are only $10 \%$ of the respondents comprised of project engineers and QA/QC staff. Data collected should be trustworthy and representative since professional respondents generally recognize as having a high level of integrity which is the most essential leadership trait from top management.

\subsection{The need of certified Green Project Manager (GPM) (Objective 1)}

Most of the respondents have agreed that GPM is a key to ensure successful delivery of green development, with the highest overall mean of 4.10. It is a standard that a Project Manager is appointed by "project owner" or "company owner" and would accomplish the responsibilities and work as per employer's order to ensure the project is complete within the allocated time and cost along with respectable quality of work. However, the issue of "green" is taking insignificant due to the PM's reluctant to think "green" in their projects unless it has been explicitly stated in the contract requirement or is an environmental requirement under the law (Kubba, 2010; Maltzman, 2010). As per example of "green" thinking by PMs in construction projects covers anticipating how to reduce noise and air pollution. Thus, it is proven that the GPM plays an important role in delivering successful green development goals.

\subsection{The limitations of promoting certified Green Project Manager (GPM) (Objective 2)}

Limited training for PM that considers sustainability elements, has the highest overall mean of 4.41 seen as the most agreed by the respondents. However, previous researchers have emphasized that training is important to promote green and sustainable status for projects in construction industry (Bourdeau, 1999; Plessis, 2007; Geoghegan\&Dulewicz, 2008; Kibwami \& Tutesigensi, 2016; Martens \& Carvalho, 2016). Nevertheless, based on the survey on participants, it is found that $66.7 \%$ of respondents did not attend any seminars or trainings on green management and only $23.33 \%$ of respondents have participated. This gap explain that Bridgit being the sole training center that promotes a specific training on GPM in Malaysia. Therefore, this shows that limited training for PM that recognize sustainability elements is one of the main barriers of promoting certified GPM.

\subsection{The success factors of promoting certified Green Project Manager(GPM) (Objective 3)}

Most of the respondent agrees that training modules able strengthens the skill among PM with the first ranking (4.50 mean). This is possible due to the need of a PM to enhance the necessary skills including being skilled in identifying green innovation as mentioned by (Mir, 2014). Hence, Bourdeau (1999) conclude that training sessions on green building show as a requirement of one factor for on- site construction personnel as a foundation towards promoting environment sustainability.

As per describe to the limitation as mentioned in objective 2, it is indicated that 4.57 mean of the respondents are strongly agreed that in order to increase the probability of producing a successful green construction in the future, the training modules is significant and beneficial indeed. Hence, training for PMs is important to provide the required skills and knowledge for them to become certified GPMs and make a true success factor.

Table 7: Summary of research finding and analysis

\begin{tabular}{|c|c|c|c|c|}
\hline Codes & Variables & Mean & Overall & Rank \\
\hline \multicolumn{5}{|c|}{ The need of certified GPM in Malaysia construction industry (Objective 1) } \\
\hline \multicolumn{5}{|c|}{ N1. Responsible to avoid cost constraint } \\
\hline N1. i & $\begin{array}{l}\text { GPM is responsible for managing and delivering projects within an allocated } \\
\text { budget. }\end{array}$ & 4.43 & \multirow{4}{*}{4.07} & \multirow{4}{*}{2} \\
\hline N1. ii & GPM is responsible for managing tighter budget on green project & 3.60 & & \\
\hline N1.iii & GPM is needed in improving project performance especially in term of cost & 4.23 & & \\
\hline N1. iv & $\begin{array}{l}\text { Appoint a competent PM in managing green is one of the solutions to ensure } \\
\text { a project is completed within established time and cost }\end{array}$ & 4.00 & & \\
\hline \multicolumn{5}{|c|}{ N2. GPM is important to ensure successful delivery of green development. } \\
\hline $\mathrm{N} 2 . \mathrm{i}$ & $\begin{array}{l}\text { There is a need for managers to think "go green" in order to deliver green } \\
\text { building }\end{array}$ & 4.13 & 4.10 & 1 \\
\hline
\end{tabular}




\begin{tabular}{|c|c|c|c|c|}
\hline N2. ii & $\begin{array}{l}\text { An experienced GPM is important to ensure successful delivery of green } \\
\text { building }\end{array}$ & 4.00 & & \\
\hline N2.iii & $\begin{array}{l}\text { PM and project team are among the key factors contributing to the success } \\
\text { of green building project implementation }\end{array}$ & 4.17 & & \\
\hline \multicolumn{5}{|c|}{ N3. PM react as catalyst "agent" to achieve goals of green } \\
\hline N3. i & Role of PM needs to be refashioned to include issues regarding green. & 3.83 & \multirow{4}{*}{3.83} & \multirow{4}{*}{3} \\
\hline N3. ii & PM direct influence ensures project success & 3.80 & & \\
\hline N3.iii & $\begin{array}{l}\text { A competent PM able to reduce carbon emissions together to maintain all } \\
\text { benefits of green abuilding }\end{array}$ & 3.70 & & \\
\hline N3. iv & $\begin{array}{l}\text { PM plays a role to enhance implementation of technological innovation for } \\
\text { success of implementation green development. }\end{array}$ & 4.00 & & \\
\hline \multicolumn{5}{|c|}{ The limitation of promoting certified GPM in Malaysian construction industry (Objective 2) } \\
\hline \multicolumn{5}{|c|}{ L1. Financial barriers } \\
\hline L1. i & $\begin{array}{l}\text { Perception of rising unsubstantiated cost among professional in construction } \\
\text { industry when dealing with sustainable construction }\end{array}$ & 4.40 & \multirow{2}{*}{4.39} & \multirow[t]{2}{*}{2} \\
\hline L1. ii & Initial extra cost is needed to implement sustainable construction. & 4.37 & & \\
\hline \multicolumn{5}{|c|}{ L2. Market Demand } \\
\hline L2. i & Lack of demand in certified green project manager. & 4.00 & \multirow{2}{*}{4.09} & \multirow{2}{*}{3} \\
\hline L2. ii & Construction is a profit driven industry & 4.17 & & \\
\hline \multicolumn{5}{|c|}{ L3. Limited training for PM that consider sustainability elements. } \\
\hline L3. i & PM trained in sustainability is a necessary element to achieve sustainable & 4.17 & \multirow{3}{*}{4.41} & \multirow{3}{*}{1} \\
\hline L3. ii & $\begin{array}{l}\text { Establishing training module for each competency will improve their } \\
\text { competency in managing green construction projects }\end{array}$ & 4.50 & & \\
\hline L3.iii & $\begin{array}{l}\text { Training module also give benefit in increasing the probability of producing } \\
\text { a successful green construction project in the future }\end{array}$ & 4.57 & & \\
\hline \multicolumn{5}{|c|}{ L4. "Going Green" is something new towards participant in the construction industry. } \\
\hline L4. i & Unclear on the concept of sustainable construction. & 3.57 & \multirow{4}{*}{3.69} & \multirow{4}{*}{4} \\
\hline L4. ii & $\begin{array}{l}\text { Confuse on the terms sustainable construction, sustainable building, green } \\
\text { construction and green building (GB) }\end{array}$ & 3.70 & & \\
\hline L4.iii & Construction player have no clear ideas on how to manage GB projects & 3.57 & & \\
\hline L4. iv & $\begin{array}{l}\text { Project management guidelines, standards and competence requirements for } \\
\text { PM tend to neglect the area of sustainability. }\end{array}$ & 3.93 & & \\
\hline \multicolumn{5}{|c|}{ L5 PM refuse to accept changing to sustainable/ green project management: } \\
\hline L5. i & Many PM and project teams are having difficulties in adapting GPM & 3.53 & \multirow{4}{*}{3.49} & \multirow{4}{*}{5} \\
\hline L5. ii & $\begin{array}{l}\text { PM more expect to use conventional practices that have been used for } \\
\text { decades }\end{array}$ & 3.50 & & \\
\hline L5.iii & There is insufficient proof on the advantages of sustainable construction & 3.40 & & \\
\hline L5. iv & Clients are not aware on sustainable construction. & 3.53 & & \\
\hline \multicolumn{5}{|c|}{ The success of certified Green Project Manager (GPM) In Malaysia construction industry (Objective 3). } \\
\hline \multicolumn{5}{|c|}{ S1. Skills and knowledge } \\
\hline S1. i & Technical knowledge regarding green technology & 4.30 & \multirow{3}{*}{4.31} & \multirow{3}{*}{2} \\
\hline S1. ii & Additional knowledge on green certificates requirement & 4.23 & & \\
\hline S1.iii & Skill and knowledge as the competencies for GPM & 4.40 & & \\
\hline \multicolumn{5}{|c|}{ S2. Training module } \\
\hline S2. i & Training as foundation for on-site construction personnel. & 4.47 & \multirow{3}{*}{4.43} & \\
\hline S2. ii & $\begin{array}{l}\text { Training module help PM competency in managing green construction } \\
\text { projects }\end{array}$ & 4.33 & & 1 \\
\hline S2.iii & Training allows strengthen the skill that PM need to improve & 4.50 & & \\
\hline & S3 Ethical aspect & & & \\
\hline S3. i & $\begin{array}{l}\text { Honesty responsibility, respect and fairness are the values that drive ethical } \\
\text { conduct for the green project management profession }\end{array}$ & 4.53 & & \\
\hline S3. ii & $\begin{array}{l}\text { Ethical aspect already accepted as a fundamental skill in project } \\
\text { administrator training and accreditation especially regarding green. }\end{array}$ & 4.10 & 4.31 & 2 \\
\hline S3.iii & $\begin{array}{l}\text { Without ethical competence, GPM will not be able to achieve } \\
\text { professionalism }\end{array}$ & 4.30 & & \\
\hline & S4. Competencies & & & \\
\hline S4. i & GPM is lacking competencies to consider the sustainability aspects of their & 4.10 & 4.25 & 3 \\
\hline
\end{tabular}




\begin{tabular}{|l|l|l|l|}
\hline & projects. & & \\
\hline S4. Ii & $\begin{array}{l}\text { Competencies of sustainable poorly stated in standard of project } \\
\text { management }\end{array}$ & 4.23 \\
\hline S4.iii & $\begin{array}{l}\text { A competency is important to develop adequate consulting skills, build } \\
\text { expertise in the aspects that determine the sustainability impact of the } \\
\text { project and complexity around the projects. }\end{array}$ & 4.43 \\
\hline
\end{tabular}

\section{CONCLUSION}

As per conclusion, a PM is responsible to handle the project within required time, cost and quality. Yet, since issue of global warming is being widely discussed around the globe and the construction industry is known to have a huge contribution on the large amount of carbon dioxide release into the atmosphere, there are a lot of initiatives that is being taken to reduce the impact of construction towards the environment. Moreover, this issue is alarming the construction industry and hence GPM is quite in need to bring a resolution to this problem. Therefore, this research briefly presents that GPM is needed to prevent cost constraint in management of green building and is crucial to successfully deliver green development as a catalyst/agent to achieve goals of green to minimize impact on the environment.

However, even after four years of launching GPM in Malaysia, there has been no proof any enhancement of this profession. Hence, more training on sustainable element and 'going green' for PM is indeed important to promote GPM in Malaysia. PM must be educated and trained to downplay their understanding of the rising of unsubstantiated cost among professional in the construction industry. Hopefully, the PM of the future would be able to accept the changes required on sustainable/green project management. Hence, the outcome of this research will become a guideline to promote certification of GPM in the future.

\section{REFERENCES}

Aarseth, W., \& Ahola, T. (2017). Project sustainability strategies: A systematic literature review. International Journal of Project Management, 1071-1083.

Abidin, N. Z. (2009). Sustainable Construction in Malaysia - Developers' Awareness. Proceedings of World Academy Of Science, Engineering And Technology, 807-814.

Aghili, N., Mohammed, A. H., \& Ting, L. S. (2016). Key Practice for Green Building Management in Malaysia. MATEC Web of Conferences, 1-5.

Aliagha, G. U., \& Hashim, M. (2013). Review of Green Building Demand Factors for Malaysia . Journal of Energy Technologies and Policy.

Ametepey.O, C. A. (2015). Barriers to successful implementation of sustainable construction in the Ghanaian construction industry. Procedia Manufacturing 3, 1682-1689.

Ashley, D. B. (1987). “Determinants of construction project success. Project Management Journal, 69-79.

Avots, I. (1969). Why Does Project Management Fail? California Management Review, 77-88.

Belassi, W., \& Tukel, O. I. (1996). A new framework for determining critical success/failure factors in projects. International Journal of Project Managemen, 141-151.

Biernacki, P., \& Waldorf, D. (1981). Snowball Sampling Problems and Techniques of Chain Referral Sampling. Sociological. methods \& research, 141-163.

Bourdeau, L. (1999). Sustainable Development and The Future of Construction: a Comparison of Visions from Various Countries. Building Research and Information, 354-366. 
Bragança, L., Mateus, R., \& Koukkari , H. (2010). Building Sustainability Assessment. Sustainability .

Brotman, B. A. (2016). The feasibility of medical office building green upgrades from an owner/lessor perspective. Journal of Property Investment \& Finance, 375-386.

Chin, Y. T. (2016). Green and Sustainable Development . 3rd International Green Workshop \& Exhibition, 9-11.

$C I D B$. (2012). Retrieved May 25, 2016, from CIDB:http://www.cidb.gov.my/cidbv4/index.php?lang=en

Davies. (2017). Barriers to Implementation of Sustainable Construction Techniques . MAYFEB Journal of Environmental Science.

Denzin, N. K. (1970). The research Act: a Theoretical Introduction to Sociological Methods. California: Aldine Pub. Co.

Environmental Sustainabilty. (2017). Retrieved $10 \quad 10, \quad 2017, \quad$ from $\quad$ CITP: http://www.citp.my/strategicthrusts/environmental-sustainability/

Eskerod, P., \& Huemann, M. (2013). Sustainable development and project stakeholder management:what standards say. International Journal of Managing Projects in Business, 36-50.

Geoghegan, L., \& Dulewicz, V. (2008). Do Project Managers' Leadership Competencies Contribute to Project Success? Project Management Journal.

Green Building Index . (2016). Retrieved 11 2, 2017, from Green Buidling Index: http://new.greenbuildingindex.org/newsFolder/news2016

Hakkinen, T., \& Belloni, K. (2011). Barriers and drivers for sustainable building. Building reseach \& information .

Herazo, B. (2012). Sustainable development in the building sector: a Canadian case study on the alignment of strategic and tactical management. Project Management journal, 84-100.

Hwang, B. G., \& Ng, W. J. (2013). Project Management Knowledge and Skills for Green Construction: Overcoming Challenges. International Journal of Project Management, 272-284

Jałocha, B., Krane, H. P., \& Ekambaram, A. (2014). Key competences of public sector project managers. 27th IPMA World Congress, 247-256.

Johnson, T. P. (2014). Snowball Sampling: Introduction. Wiley Online Library.

Khalfan, M., Noor, M. A., \& Maqsood, T. (2015). Perceptions towards Sustainable Construction amongst Construction Contractors in State of Victoria, Australia. Journal of Economics, Business and Management.

Khodadadzadeh, T. (2016). Green building project management: obstacles and solutions for sustainable development. Journal of Project Management.

Kibwami, N., \&Tutesigensi, A. (2016). Enhancing Sustainable Construction in the Building Sector in Uganda. Habitat International, 64-73.

Kissi, J., \& Dainty, A. (2013). Examining the Role of Transformational Leadership of Portfolio Managers in Project Performance . International Journal of Project Management.

Kubba, S. (2010). Green Construction Project Management and Cost Oversight. United State: Elseveir Inc.

Li, Y. Y., Chen, P. H., \& Chew, D. A. (2011). Critical Project Management Factors of AEC Firms for Delivering Green Building Projects in Singapore. Journal Of Construction Engineering And Management, 1153-1163 
Liikamaa, K. (2015). Developing a project manager's competencies: A collective view of the most important competencies. 6th International Conference on Applied Human Factors and Ergonomics (AHFE 2015) and the Affiliated Conferences, AHFE 2015, 681-687.

Lokman, M. A., \& Abdullah, M. N. (2017). Exploring Competencies for Green Building Project Manager. International Journal of Real Estate Studies.

Maltzman, R., \& Shirley, D. (2010). Green Project Management. U.S: Taylor \& Francis Group.

Marshall, B., \& Cardon, P. (2013). Does Sample Size Matter In Qualitative Research ?: A Review of Qualitative Interview isin research. Journal of Computer of Information System.

Martens, L. M., \& Carvalho, M. M. (2016). Key factors of sustainability in project management context : A survey exploring the project managers's perspectif. International Journal of Project Management, 1084-1102.

Mir, F. A., \& Pinnington, A. H. (2014). Exploring the Value of Project Management: Linking Project Management Performance and Project Success . International Journal of Project Management, 202-207.

Mishra, P., \& Dangayach, G. (2011). An Ethical approach towards sustainable project Success . International Conference on Asia Pacific Business Innovation \& Technology management, 338-344.

Mokhtariani, M. (2017). Construction Marketing: Developing a Reference Framework. Advances in Civil Engineering.

Moradi , A. M., Hosseini, B., \& Yazdani, H. (2018). Principles of assessment and improvement of construction systems environmental sustainability in Iran (By Life cycle Numerical Parametric Measurement Approach). International Journal of Architectural Engineering \& Urban Planning .

Muller, R., \& Turner, R. (2010). Leadership Competency Profiles of Successful Project Managers. International Journal of Project Management, 437-448.

Nauman, S., \& Khan, M. A. (2010). Patterns of Empowerment and Leadership Style in Project Environment. International Journal of Project Management, 635-649.

Neyestani, B. (2017). A Review on Sustainable Building (Green Building). Department of Civil Engineering, De La Salle University, Manila.

Okland, A. (2015). Gap Analysis for Incorporating Sustainability in Project Management. Procedia Computer Science , 103-109.

Omair, A. (2014 ). Sample size estimation and sampling techniques for selecting a representative sample. Journal of Health Specialties , 142-147.

Plessis, C. D. (2007). A Strategic Framework for Sustainable Construction in Developing Countries. Construction Management and Economics, 67-76.

Robichaud, L. B., \& Anantatmula, V. S. (2011). Greening Project Managment Practices for Sustainable Construction. Journal of management in engineering, 48-57

Sadaba, S. M., Jaen, L. F., \& Ezcurdia, A. P. (2015). Using Project Managemnet as a Way to Sustainability. From a Comprehensive Review to a Framewok Definition. Journal of Cleaner Production, 1-16

Saleh, M. S. (2015). Towards sustainable construction in Oman: Challenges \& Opportunities . International Conference on Sustainable Design, Engineering and Construction, 177-184. 
Shi, Q., Yan, Y., \& Zuo, J. (2016). Objective conflicts in green buildings projects: A critical analysis. Building and Environment, 107-117.

Silvius, G. A., \& Schipper, R. P. (2014). Sustainability in Project Management Competencies: Analyzing the Competence Gap of Project Managers. Journal of Human Resource and Sustainability Studies, 40-58.

Sourani, A. (2011). Barriers to addressing sustainable construction in public procurement strategies. Engineering Sustainability, 229-237.

Tabassi, A. A., \& Argyropoulou, M. (2016). Leadership Behavior of Project Managers in Silvius, G. A., \& Schipper, R. P. (2014). Sustainability in Project Management Competencies: Analyzing the Competence Gap of Project Managers. Journal of Human Resource and Sustainability Studies, 40-58.

Vyas, G. (2017). Benchmarking green building attributes to achieve cost effectiveness using a data envelopment analysis. Sustainable Cities and Society, 127-134.

Walker, B. L., \& Walker, D. (2011). Authentic Leadership for 21 st century project delivery. International Journal of Project Management, 383-395.

Wang, N., Yao, S., \& Wu, C. C. (2015). Critical factors for sustainable project management in public projects. International Association for Management of Technology.

Webb, E. J., Campbell, D. T., \& Schwartz, R. D. (1966). Unobtrusive Measures: Nonreactive Research in the Social Sciences. England: Oxford.

Yang, L. R., Huang, C. F., \& Wu, S. K. (2011). The Association Among Project Manager's Leadership Style, Teamwork and Project Success. International Journal of Project Management, 258-267. 